\title{
Review of Snow Data Assimilation Methods for Hydrological, Land Surface, Meteorological and Climate Models: Results from a COST HarmoSnow Survey
}

\author{
Jürgen Helmert ${ }^{1, *}$, Aynur Şensoy Şorman ${ }^{2}$, Rodolfo Alvarado Montero ${ }^{3}$, Carlo De Michele ${ }^{4}(\mathbb{D}$, \\ Patricia de Rosnay ${ }^{5}{ }^{(0}$, Marie Dumont ${ }^{6}\left({ }^{\circ}\right.$, David Christian Finger ${ }^{7}$, Martin Lange ${ }^{1}$, \\ Ghislain Picard ${ }^{8}$ (D) , Vera Potopová ${ }^{9}$, Samantha Pullen ${ }^{10}$, Dagrun Vikhamar-Schuler ${ }^{11}$ \\ and Ali Nadir Arslan 12 (D) \\ 1 Deutscher Wetterdienst (DWD), Offenbach 63067, Germany; Martin.Lange@dwd.de \\ 2 Anadolu University, Faculty of Engineering, Department of Civil Engineering., Eskisehir 26555, Turkey; \\ asensoy@anadolu.edu.tr \\ 3 Deltares, Operational Water Management Department, Delft 2600 MH, The Netherlands; \\ Rodolfo.AlvaradoMontero@deltares.nl \\ 4 Politecnico di Milano, Department of Civil and Environmental Engineering, P.zza L. da Vinci 32, Milano \\ 20133, Italy; carlo.demichele@polimi.it \\ 5 European Centre for Medium-Range Weather Forecasts (ECMWF), Reading RG2 9AX, UK; \\ patricia.rosnay@ecmwf.int \\ 6 Météo-France-CNRS, CNRM, UMR 3589, CEN, Saint Martin d'Hères F-38400, France; \\ marie.dumont@meteo.fr \\ 7 School of Science and Engineering, Reykjavik University; Reykjavik, 101, Iceland; fingerd@gmx.net \\ 8 UGA, CNRS, Institut des Géosciences de l’Environnement (IGE), UMR 5001, Grenoble 38041, France; \\ ghislain.picard@univ-grenoble-alpes.fr \\ 9 Department of Agroecology and Biometeorology, Czech University of Life Sciences Prague, Kamycka 129, \\ Prague 165 21, Czech Republic; potop@af.czu.cz \\ 10 Met Office, FitzRoy Road, Exeter, Devon EX1 3PB, UK; samantha.pullen@metoffice.gov.uk \\ 11 Norwegian Meteorological Institute, Oslo 0313, Norway; dagrun@met.no \\ 12 Finnish Meteorological Institute, Helsinki FI-00560, Finland; ali.nadir.arslan@fmi.fi \\ * Correspondence: juergen.helmert@dwd.de; Tel.: +49-69-8062-2704
}

Received: 28 September 2018; Accepted: 7 December 2018; Published: 14 December 2018

\begin{abstract}
The European Cooperation in Science and Technology (COST) Action ES1404 "HarmoSnow", entitled, "A European network for a harmonized monitoring of snow for the benefit of climate change scenarios, hydrology and numerical weather prediction" (2014-2018) aims to coordinate efforts in Europe to harmonize approaches to validation, and methodologies of snow measurement practices, instrumentation, algorithms and data assimilation (DA) techniques. One of the key objectives of the action was "Advance the application of snow DA in numerical weather prediction (NWP) and hydrological models and show its benefit for weather and hydrological forecasting as well as other applications." This paper reviews approaches used for assimilation of snow measurements such as remotely sensed and in situ observations into hydrological, land surface, meteorological and climate models based on a COST HarmoSnow survey exploring the common practices on the use of snow observation data in different modeling environments. The aim is to assess the current situation and understand the diversity of usage of snow observations in DA, forcing, monitoring, validation, or verification within NWP, hydrology, snow and climate models. Based on the responses from the community to the questionnaire and on literature review the status and requirements for the future evolution of conventional snow observations from national networks and satellite products, for data assimilation and model validation are derived and suggestions are
\end{abstract}


formulated towards standardized and improved usage of snow observation data in snow DA. Results of the conducted survey showed that there is a fit between the snow macro-physical variables required for snow DA and those provided by the measurement networks, instruments, and techniques. Data availability and resources to integrate the data in the model environment are identified as the current barriers and limitations for the use of new or upcoming snow data sources. Broadening resources to integrate enhanced snow data would promote the future plans to make use of them in all model environments.

Keywords: COST Action ES1404; HarmoSnow; snow measurements; snow models; data assimilation; remote sensing

\section{Introduction}

As a major part of the cryosphere, snow is an important component of the hydrological cycle and with its unique physical properties, it is an essential environmental variable directly affecting the Earth's energy balance. Proper description and assimilation of snow information into hydrological, land surface, meteorological and climate models is therefore important to address the impact of snow on various phenomena such as hydrological monitoring, avalanche forecast, and weather forecast, to predict snow water resources and to warn about snow-related natural hazards [1-9].

Understanding the microstructural, macrophysical, thermal and optical properties of snowpack is essential [10] and there is a great need for accurate snow data at different spatial and temporal resolutions to address the challenges of changing snow conditions.

Distinctive snow properties are currently determined by traditional ground-based measurements as well as remote sensing, over a range of scales, following considerable developments in instrument technology over recent years. Snow measurements are becoming increasingly important for freshwater management, mitigation of climate changes, adaptation to new climate conditions, and risk assessments such as avalanches, floods [11], and droughts [12].

At the present time in situ measurements of the snowpack state are performed on the ground at numerous stations (e.g., WMO synoptic stations) and during intensive field campaigns (e.g., [13-17]). Simultaneous measurements of snow properties and soil properties are of further advantage [18] but only available at selected stations. However, depending on the region, in situ measurements could have a relatively coarse spatial coverage and are only representative of a limited area due to spatial heterogeneities of snow [19-21]. An increase in the number of snow measurements from national high-resolution weather networks integrated into the WMO GTS (Global Telecommunication System) and WIS (WMO Information System) would thus provide a clear benefit [22]. With the implementation of the Global Cryosphere Watch (GCW) in 2011, the WMO established a program that considers the growing demand for authoritative information on past, present and future state of the world's snow and ice resources [23]. Although GCW is global in scope, the program needs activities at all scales, including regional, national and local levels [24] and recognizes the requirements for assimilation, model development and validation.

Space-born remote sensing data have the potential to provide estimates of certain snow properties [25]. In the visible (VIS) and near infrared (NIR) spectral range space-borne remote sensors (e.g., MODIS, AVHRR, Sentinel-2) can determine the snow cover extent (SCE) and snow cover fraction (SCF) at a high spatial resolution and long time-series of these data exist (e.g., [26-33]). The observation of snow cover area is of particular value in headwaters of mountainous regions [34-36] and one can expect to obtain volume information thanks to recent advances in photogrammetry and in the availability of stereo image [37]. In addition, remotely sensed daily SCE has been shown to improve performance of hydrological models applied to various catchments in Austria [38,39], Italy [40,41], Switzerland [8,42,43], Turkey [34,44-46], Iceland [47] and the USA [48]. 
Optically derived snow cover products are considerably limited by the presence of clouds [49], which results in spatiotemporal gaps [25]. This limitation was quantified by [38], who found that, on average, clouds obscured $63 \%$ of Austria in MODIS daily snow maps, from February 2000 to December 2005. Similarly, [50] found that, on average, clouds obscured 55\% (MODIS Aqua) and 50\% (MODIS Terra) of Po river basin (Northern Italy), for the period 2003-2012. Interestingly, they have pointed out that in the Alpine region of the basin (>1000 m.a.s.l.), the presence of clouds increases during the melting season when SCE and SCF products are most relevant: on average the percentage of cloud obstruction is $70 \%$. Thus, cloud removal procedures are necessary to mask clouds for the snow product to be used or assimilated in hydrologic and land surface models. In the literature, different cloud removal procedures were developed based on temporal and spatial filters, see, e.g., for MODIS products [39,50-55]. In addition, digital imagery for snow extent monitoring [56] are conducted with a newly developed system for acquisition, processing and visualization of image time series from multiple camera networks [57]. These systems could connect in situ measurements and remote-sensing products and could provide SCE information in overcast conditions.

Passive microwave sensors can measure snow mass (snow water equivalent, SWE) and are not affected by illumination (night, clouds), which limits optical data during much of the high latitude snow season [58-60]. However, the spatial resolution of passive microwave SWE data is currently too coarse for many watershed-scale hydrological applications in mountainous regions $[30,61]$, and point gauge snow data have sparse and uneven spatial coverage [62] and their accuracy is sensitive to the assumptions used, the topography, and properties of the snow pack (e.g., [63-71]). Alternatively, active microwave sensors have the potential to determine snow depth or mass from space with higher resolution but require spaceborne measurements at appropriate frequencies (Ku-band) [25] and the time resolution is more limited than for passive microwave sensors. In addition, the signal is sensitive to the snow layer properties, which complicates direct estimation of SWE from the satellite signal. For example, based on the Synthetic Aperture Radar (SAR) Interferometry technique and Sentinel-1 data, Snow Water Equivalent (SWE) temporal variations with sub-centimeter measurement accuracy can be retrieved with up to $20 \mathrm{~m}$ spatial resolution in any weather and sun illumination condition [72].

In addition to the determination of snow characteristics by in situ and remotely sensed measurements, another approach to obtain snow properties is to use physical or conceptual snow evolution modeling. Three major classes of snowpack models are employed for various applications [73]: single-layer snow scheme (e.g., [74]), scheme of intermediate complexity (e.g., [75]) and detailed snowpack models, which differ in the description and the parameterization of the properties inside the snowpack and the related processes [76-78]. Single-layer representations of snow thermodynamics are still used in operational NWP models [20]. In more advanced land surface schemes employed by operational models multi-layer snow options with fixed or variable numbers of layers are available [20], e.g., HTESSEL at ECMWF [79], JULES at the Met Office [80], ISBA-ES in SURFEX [81], and TERRA in the ICON model at DWD [82]. Detailed snowpack models include in addition state variables for snow microstructure, namely grain sizes and shapes in layers $[20,83]$. However, continuous estimates of the snow state from numerical model predictions are still limited by scarcity and uncertainties in meteorological forcing data (see [84] for an example) and model structural problems for snow processes in land surface models [25,85-87].

Assimilation of remotely sensed snow-related observations and ground-based snow measurements has been proven to be an effective method to improve hydrological and snow model simulations [88-93]. Therefore, the potential of data assimilation methods to consistently improve model simulations of the snow state by assimilation of measurements from in situ as well as from remote sensing has received continuously increasing attention [25,59,88-102]. With data assimilation (DA hereinafter) techniques, an improvement of the simulated snow properties from numerical models can be obtained by the combination of observational datasets with numerical model predictions and consideration of the uncertainties of observed and modeled variables [103]. Several studies report the assimilation of in situ snow observations [62,101,103-105] even for operational 
applications $[2,106,107]$. A number of snow DA experiments taking into account remotely sensed snow properties have been performed with different observational datasets, including snow covered area and SWE $[59,88,90,91,100,108,109]$.

However, visible or near-infrared observations do not allow assimilation updates under cloudy conditions and the updates depend on the snow depletion curve used to relate SCE or SCF to SWE [25]. Direct assimilation of SWE from passive microwave remote sensing data exists $[88,100,110]$ but radiance assimilation may be more effective $[25,111-118]$. The latter approach is indeed able to overcome the difficulty arising from the non-unique and complex relationship linking the passive microwave signal and several snow properties (e.g., density, grain size/microstructure parameters, temperature and wetness). To assimilate radiance, radiative transfer modeling is needed to play the role of the 'observation operator' in the DA scheme, that is to relate the snow properties predicted by the dynamical snow scheme to the remotely-sensed observed variables as well as to provide the associated uncertainties [119]. Many such numerical models have been developed and evaluated over the last decade for the passive microwave such as HUT [120], MEMLS [121], DMRT-QMS [122], DMRT-ML [123]. Although their performances appear to be comparable (e.g., [124]), the formulations and parameterizations used in each model are diverse. This apparent paradox is only partially understood (e.g., [125,126]), which has motivated the development of a uniform, harmonized, modeling platform called the Snow Microwave Radiative Transfer Model (SMRT, [127]). This new model is also able to better represent the snow microstructure, which currently remains the main bottleneck for SWE estimation $[114,128]$.

The European Cooperation in Science and Technology (COST) promoted and funded the Action ES1404 called "A European network for a harmonized monitoring of snow for the benefit of climate change scenarios, hydrology, and numerical weather prediction," or "HarmoSnow" for short. The HarmoSnow project (2014-2018) coordinates efforts towards harmonized snow data processing and handling practices by promoting new observing strategies, bringing together different communities, facilitating data transfer, upgrading and enlarging knowledge through networking, exchange and training, and linking them to activities in international agencies and global networks [129]. Due to the large heterogeneity of methods and tools for manual measurement of snow and their assimilation in numerical models one of the first activities of HarmoSnow was to carry out surveys to obtain an updated picture of the existing variety of a) snow measurement practices and instrumentations, and b) the data assimilation methods and snow data processing used in NWP, hydrology, and climate studies by the European institutions. The results of the first survey are published in [11]. This paper aims to assess the current situation and understand the diversity of usage of snow observations in DA, forcing, monitoring, validation, or verification within NWP, hydrology, snow and climate models. Our findings are based on the responses from the community to the second survey, on snow DA methods and processing, and on literature review.

\section{European Survey on Usage of Snow Observations in Data Assimilation, Forcing, Monitoring, Validation, or Verification}

The survey was conducted via an online questionnaire from September 2015 to December 2017 on the COST HarmoSnow website. This questionnaire (see Supplementary Material: COST ESSEM 1404 working group 3 survey: Questionnaire and results) was compiled by COST HarmoSnow experts in snow modeling and data assimilation and distributed across the COST, EUMETSAT H-SAF and GCW member networks. The questionnaire was answered by 51 participants from 31 countries. The survey consists of 32 questions in six sections and one text box for additional comments (see Supplementary Material: COST ESSEM 1404 working group 3 survey: Questionnaire and results), which are also available at the COST HarmoSnow website. Most questions used multiple choice answers. This procedure ensures clear answers and space for further explanations was provided. A weighting of the answers was not made, but we are aware of their heterogeneity in terms of 
institutional representativeness and implications for the representativeness of our derived conclusions. The evaluation was performed manually.

\section{Results}

The results of the survey are presented in this section, grouped into sub-sections according to the thematic topic that the survey questions address. Description and interpretation of the results is therefore separated into: the range of participants in the survey; the modeling environments used by participants, the data assimilation methods used; snow observations used in these DA methods; treatment of background and observation errors; quality control methods used; data exchange policy and requirements; and plans for future observation use.

\subsection{Participating Countries and Institutions}

The distribution of the number of answers among the countries is shown in Figure 1. It shows that all responses were from countries from the northern hemisphere, with the majority from central Europe (27). With the Nordic countries, Russian Federation, the USA and Canada, most countries in the boreal forest belt answered the survey. These countries contain regions that always have seasonal snow in northern hemisphere winter, while for countries in central and southern Europe the number of days with snow cover is more variable and depends on several factors. For reporting countries having relatively lower latitude and high altitudes, snow in the climatological mean is limited to the mountains, however it is an important factor for meteorological and hydrological applications. Most European countries involved in the COST action provided at least one answer, thus the dataset of answers provides a solid base for analysis to obtain an overview on the utilization of snow data in NWP systems, hydrological models, special snow models and treatment of snow in other model environments (Figure 2).

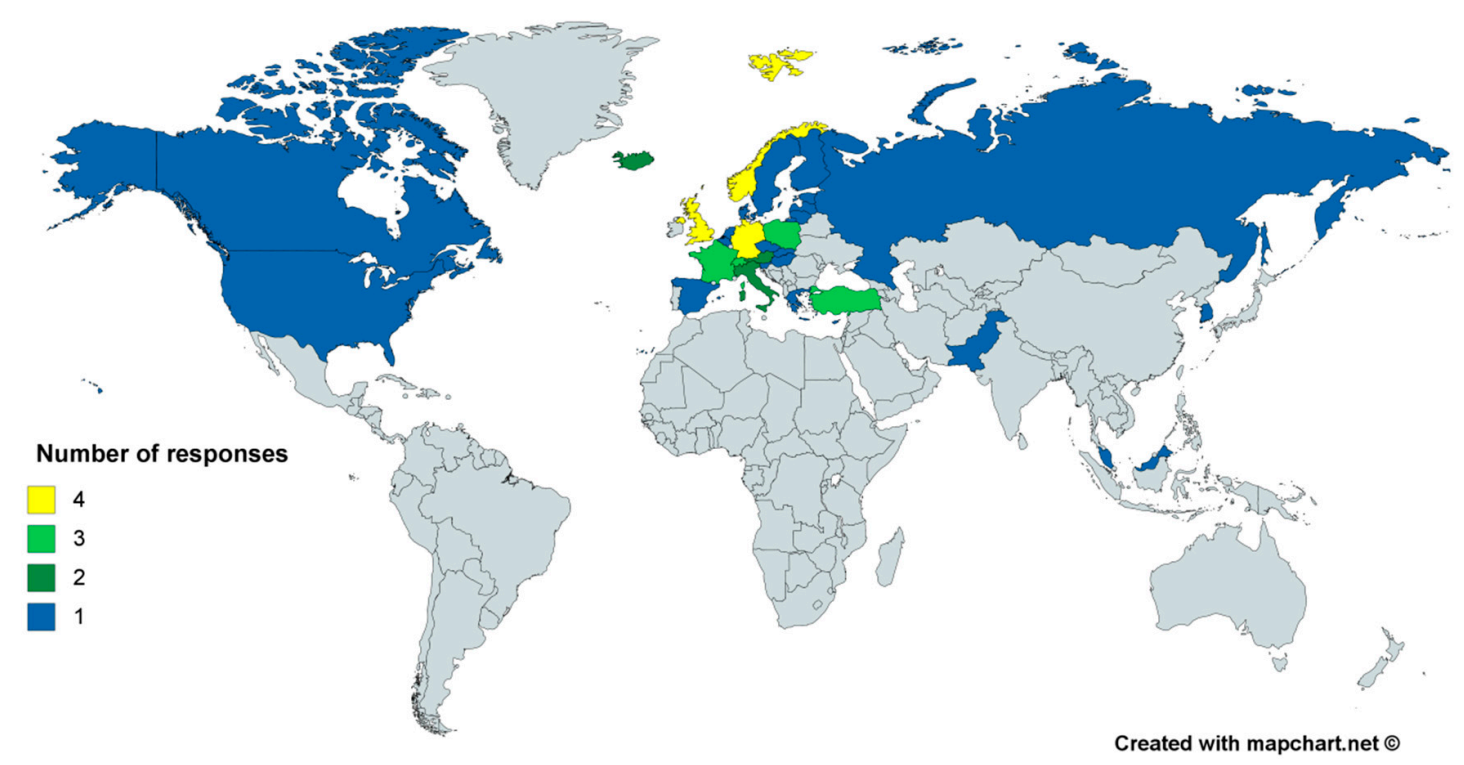

Figure 1. Geographical distribution of number of responses in the survey. 


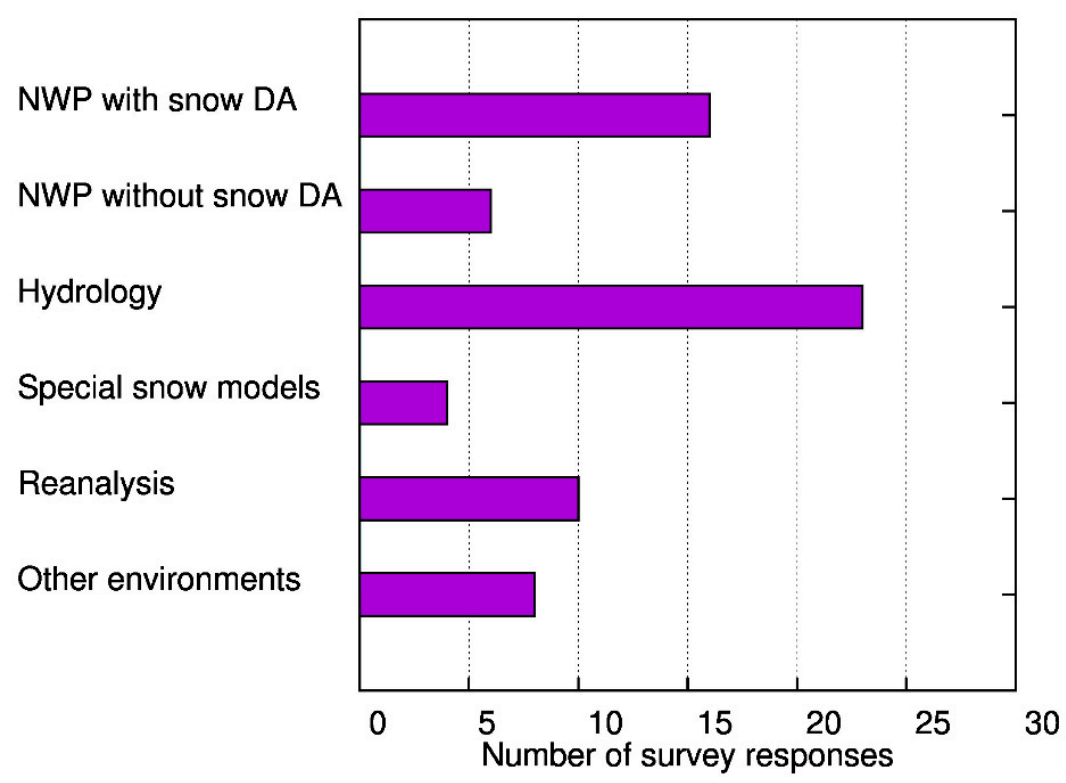

Figure 2. Distribution of modeling environment within the questionnaire.

In general, multiple responses from each country were not expected since most snow DA activity takes place within the national met service of that country, which is a fairly standard situation in most European countries. The national weather services in the countries with huge territories (Russia, Canada and the USA) include regional institutions with their own capabilities to produce local weather forecasts.

\subsection{Modeling Environment, Model Domain and Resolution}

The assessment results have been partitioned according to the type of modeling environment that the respondent has identified as using. Among respondents, 16 institutes use numerical weather prediction models (full or limited area) with DA, six without DA, 23 institutes use hydrological models (e.g., conceptual, operational, snowmelt models, runoff models, etc.), 10 institutes use reanalysis and four institutes employ special snow models. In eight institutes other (miscellaneous) models (e.g., snow cover, land surface, multi-layer snow), with snow observations are used (Figure 2). In addition to meteorological and hydrological services, 11 universities and two companies participated in the survey. The resolutions of the models span from the global scales down to kilometer scale resolutions and even to the river catchment areas according to the modeling environment, clearly proving the declared importance of snow observations over a range of spatial scales.

\subsection{Data Assimilation Methods}

There are differences in the snow DA methods used by the various model environments as well as in the update frequency of snow observations and the required time interval for consideration of the measurement. Depending on their degree of complexity, DA techniques are characterized by different performances. The sequential DA techniques are widely used for real-time applications. They sequentially update the model state using observational data as they become available [102]. Basic approaches are based on direct insertion (DI) methods $[104,108,130]$ or Cressman interpolation $[2,131,132]$. Other approaches include optimal interpolation (OI) schemes $[103,107,133,134]$ and the nudging method $[135,136]$, which take into account the observational uncertainty [102].

The Kalman filters [137] are approaches based on least-squares analysis method. The standard version of the Kalman Filter (KF) [138] still depends on the assumption of system linearity since it explicitly takes into account the dynamical nature of model and observation errors, which evolve with 
time, to produce a statistically optimal model state estimates for linear systems. The Extended Kalman Filter (EKF) [139] allows consideration of nonlinear dynamic models using a linearized statistical approach [59,110]. With the Ensemble Kalman Filter (EnKF) the inaccuracy of the linearization procedure, which affects the filter performance due to possible strong model nonlinearities [140], can be avoided [141]. An ensemble of possible model realizations is needed based on the Monte Carlo approach [142] to determine the error estimates instead of a model linearization. Other, more sophisticated methods, that include for example particle filter [143], are also used for snow data assimilation in hydrology. Similar to the EnKF, the particle filter (PF) is a sequential Monte Carlo simulation $[43,90,97,117,143-147]$ and accounts for uncertainties in the forcing data, model structure and observations. However, in contrast to the EnKF the PF does not depend on the assumptions of Gaussian distribution of errors or the assumption of Gaussian joint probability density function (PDF) on the state variables and observations $[19,148]$. This allows the PF to characterize the full probability distribution of state variables and consequently their uncertainties more accurately by resampling sets of state variables, i.e., particles with higher posterior weights, as opposed to the linear model state updating of the EnKF [19]. Another DA approach is the variational Moving Horizon Estimation (MHE), which optimizes an objective function within an assimilation window using numerical approximations [149]. This type of methods is also applied in Model Prediction Control applications when the assimilation window is shifted to the predictive horizon [150]. Recently, [151] extended this approach to consider multi-parametric conditions in consideration with snow DA.

Despite the previous drawbacks, EnKF techniques have been widely implemented to process snow observation data $[19,20,62,88,111,152-156]$. Also in snow hydrology, an increasing number of studies confirm the advantages of EnKF as a data assimilation method, which improves the accuracy of hydrological simulations through the assimilation of snow-related observations $[25,62,88,89,101,102,111,152,157-160]$. Other studies have shown the benefits of assimilation of snow using EKF [59,110] or PF [19], while [100] applied the MHE to evaluate different satellite products, including snow observations, within the DA procedure.

The results of the survey show that the OI method and EnKF are the most commonly used methods (Figure 3). The survey revealed that snow DA for NWP mostly relies on optimal interpolation (OI) schemes [107] or Cressman interpolation [131], on the other hand Kalman filters [137] or EnKF methods [141] are generally used for hydrological applications. Other answers in the survey include Moving Horizon Estimation, Nudging, Asynchronous EnKF, Bias Detecting Ensemble, simple exchange of initial values, and simple update method. However, it should be noted that for complex multi-layered snow models, the application of conceptually simple DA schemes is not straightforward due to possible model spin-up behavior resulting from physical inconsistencies among state variables $[97,161]$.

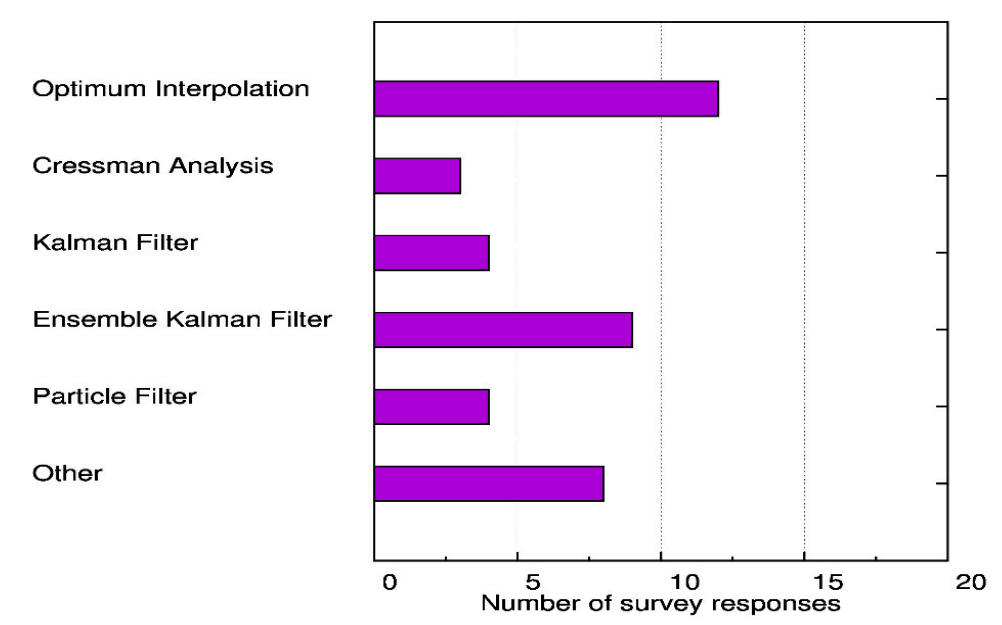

Figure 3. Data assimilation methods. 
The survey results confirm the existing gap of applied sophistication in DA methods for operational NWP, i.e., the DA methods used for snow analyses in NWP are much simpler than the state of the art in DA [20] and lag behind the level of sophistication used for the initialization of other surface variables (e.g., soil moisture). Furthermore, operational NWP systems assimilate snow depth from in situ ground measurements and satellite-derived snow extent $[2,134,162]$ but SWE is not considered during the assimilation cycle [20]. Recent effort to implement advanced techniques such as the particle filter [163], show promising results, although the path toward operational use is long [97].

\subsection{Snow Observations in Data Assimilation through Different Models}

Snow observations from SYNOP and additionally ground-based measurements are the most important data sources for NWP and hydrologic models (Figure 4). For the latter, ground-based remote sensing data are also very important. The most important snow parameters used in DA are snow depth and SWE, which are processed by incremental update for NWP or update of absolute values in hydrologic and other snow models.

SYNOP

Non-SYNOP ground

Remote sensing

- ground based

- satellite (radiances)

- satellite (SAF)

Climatological data sets

External analysis

Other

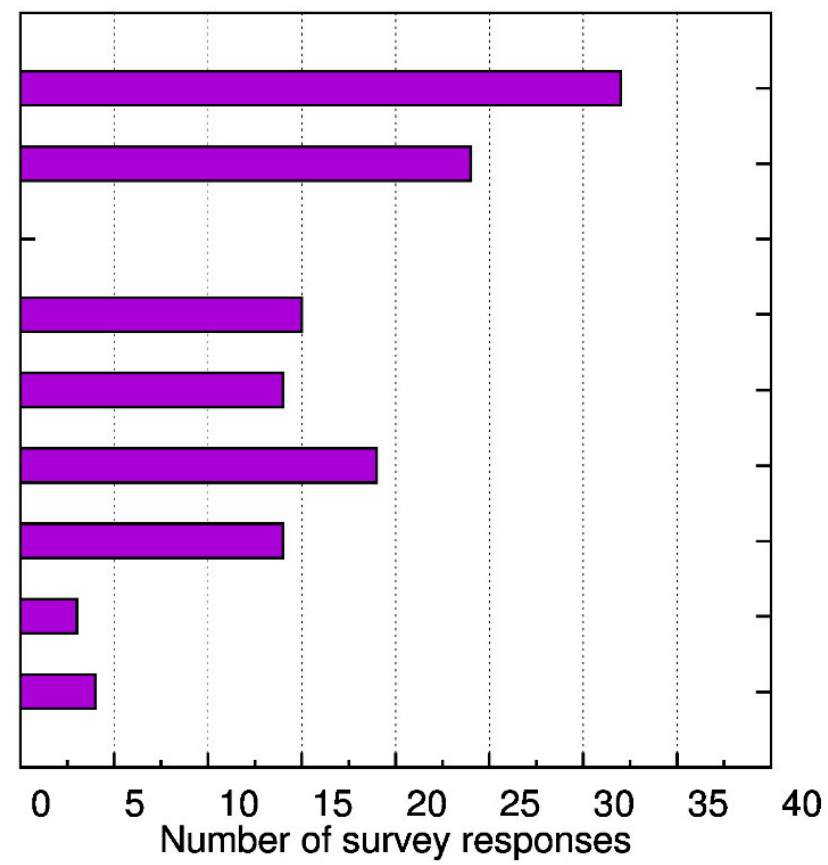

Figure 4. Snow observations and products used in the modeling system.

According to the answers, snow height (depth) is the most preferable information for DA in NWP models. For these data, the importance of an active reporting of snow-free conditions (zero snow depth) in the SYNOP messages together with the exchange of non-GTS stations data is crucial. For hydrologic models, both snow height (depth) and SWE are popular for use in DA, as complementary products to streamflow assimilation. For this group of models, forcing variables (precipitation, temperature) can also be used in the assimilation process to update state variables. The main snow variable analyzed in almost every type of model is SWE.

Most hydrologic model users that responded to the survey use ground-based remote sensing measurements, while this is not the case for NWP or reanalysis users. The ground-based measurement systems include ultrasonic or laser distance sensors, photogrammetry, COSMIC neutron sensors and others. Further details on in situ snow measurements are given in the results of the parallel COST HarmoSnow survey on in situ snow measurement practices and techniques, [11].

Preprocessed remote sensing satellite products are also often used in both NWP and hydrology. Satellite radiances are used much less and climatological data are appropriated for hydrological 
applications. Additional data, used by survey participants include external snow analysis or multi-sensor satellite products. Preprocessed snow products are used in all model environments but these products have special importance in NWP without DA, reanalysis and miscellaneous models. The used products are, e.g., from IMS snow cover, satellite (MODIS, SEVIRI, AVHRR), SAF (H-SAF, LSA-SAF), NWP-based snow analysis or reanalysis.

The process of analyzing variables is mostly incremental update of first guess from model forecast for NWP models and update of absolute values for hydrological models. However, the modelers use both processes together in some applications. Model forecasts are the main background field used in snow data assimilation for all model types. However, a very limited number of answers include pre-analysis or external analysis and climatology as a background field.

Independently of the modeling environment most DA systems perform a snow analysis every $24 \mathrm{~h}$ (Figure 5). This is important for the assimilation of remote sensing data since not all satellite products are available on a daily basis. Even daily products for SWE based on passive microwave remote sensing data have a coarse resolution (in the order of tens of kilometers) while SWE products from active microwave sensors can reach a resolution of tens of meters but are only available every few days (e.g., 35 days with ERS and Environmental Satellite (ENVISAT) in the past decades and nowadays six days with Sentinel 1).

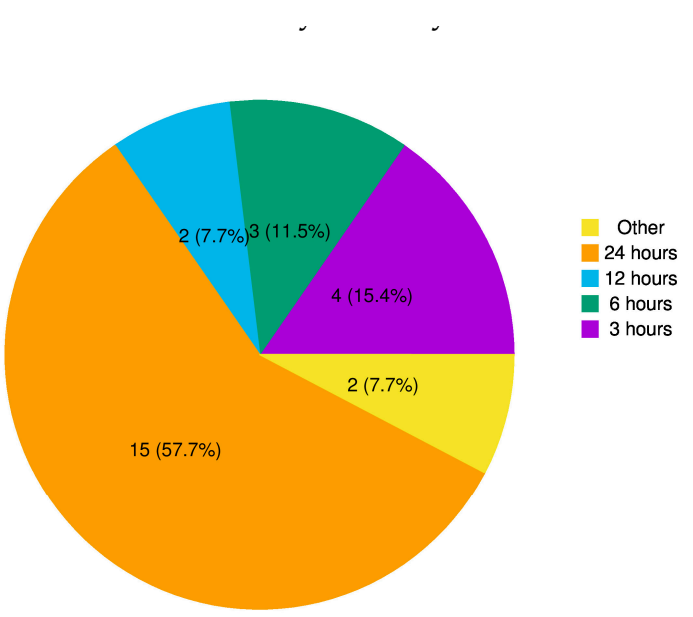

(a)

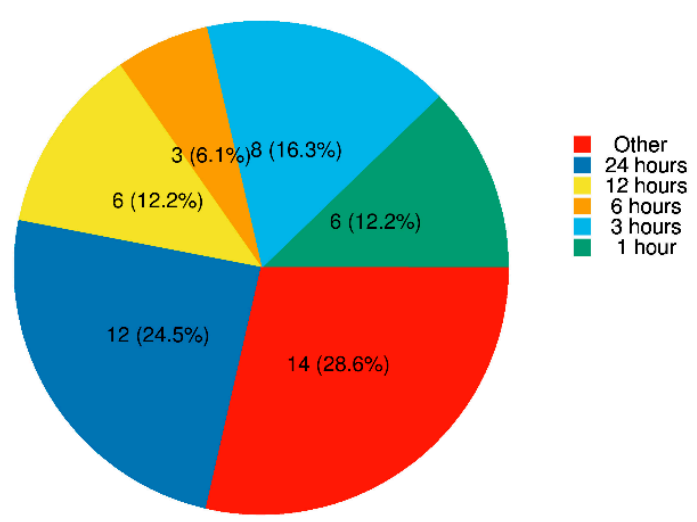

(b)

Figure 5. Update frequency for snow data assimilation (a) and observation latency (b).

The observation data latency, i.e., the time from the measurement acquisition to the availability in a numerical model is another important parameter, which has to be considered for time-critical applications. More than $50 \%$ of the survey answers indicate that the observation latency should not exceed $24 \mathrm{~h}$. For research applications or in climate studies, a longer latency might be acceptable. However, more than $25 \%$ of the answers show that the observations should be available within $3 \mathrm{~h}$, which is a strong constraint for the observation data processing and exchange.

\subsection{Background and Observation Error Estimations Used in Snow Data Assimilation}

The background error estimates are done either by distance weighting or taken as a fixed value in most of the NWP models, the former is more commonly used compared to the latter. The variance of ensembles is another method used in limited applications. A few institutes working on NWP also indicated that background errors are not accounted for in their system. For the other model communities, the answers are more varied and include no estimate, fixed value, distance weights, stochastic noise, defined algorithms with clearly more emphasis on variance of ensembles, which is most likely due to the choice of EnKF for DA methodology. 
According to the survey there is no standard approach for observation error estimates. Generally, standard deviations or fixed values according to the measurement errors (in principle different for different observation types) are used in NWP models. Some of the institutes do not use error estimates assuming uncorrelated observed data except for the anomalous observations identified and rejected by quality control procedures. In the other modeling environments, observation errors are defined by measurement errors, standard deviations, confidence intervals, rough estimates, stochastic noise, error covariance matrices, or error estimates are simply not accounted for.

Observation error specification has a large impact on DA efficiency. Figure 6 illustrates the two-meter air temperature forecast (range 12-h and 3-day) difference from December 2016 to February 2017, between a test experiment, where the snow observation error was doubled in the ECMWF snow DA, and a reference experiment, using the ECMWF operational system [134]. It shows generally colder conditions in the northern hemisphere. Doubling the observation error gives relatively more weight to the model background in the test experiment compared to the reference experiment. Since the ECMWF model tends to overestimate snow, this results in more snow on the ground in the test than in the reference experiment, and therefore generally lower air temperature forecasts. Slight and noisy differences in non-snow-covered areas are non-significant and due to the fact that the test and the control experiments differ.

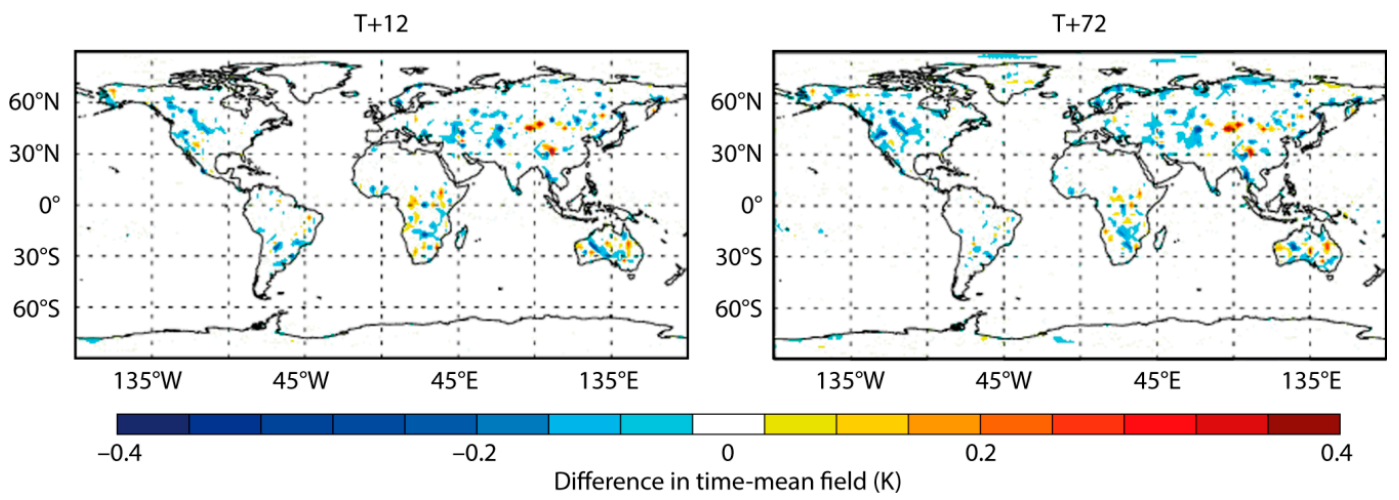

Figure 6. Impact, shown as mean temperature difference in K (01 December 2016 to 28 February 2017), of doubling snow observation error in the ECMWF snow data assimilation system used for NWP, on two-meter air temperature $12-\mathrm{h}$ and $72-\mathrm{h}$ forecasts.

\subsection{Quality Control of Snow Observations or Products}

One of the important features of DA systems is the quality control of the data [164]. It is performed by using previous model forecasts for comparison with observations. This allows identification and elimination of spurious data. Furthermore, it is possible to calibrate observing systems and identify biases or changes in observation system performance when this comparison is performed repeatedly [165].

Quality control of snow observations and products is performed in the large majority of the model environments used in this survey (Figure 7.). Filtering of outliers, manual and automatic treatment of missing data or implausible values is used in all model environments with different levels of sophistication. DA in NWP is used for this purpose, as some responses from the survey show. 


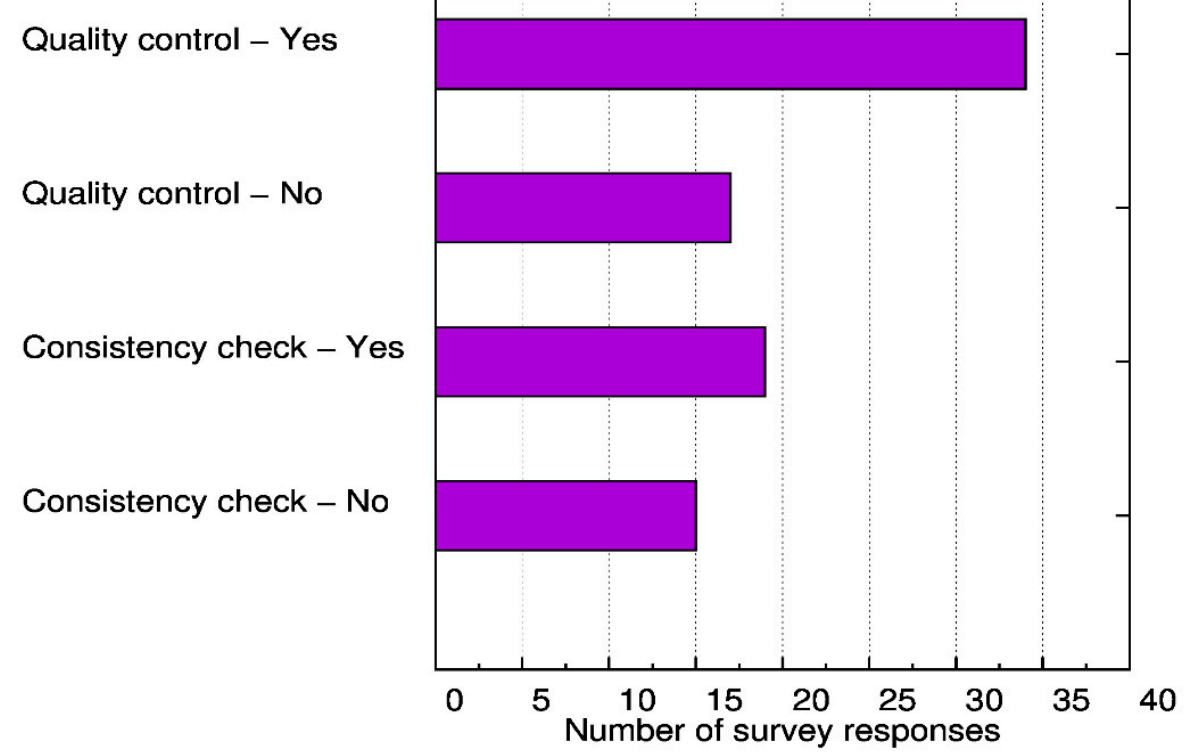

Figure 7. Quality control and consistency check of snow observations or products.

Consistency or sanity checks are used to examine whether the observation absolute value or rate of change with time is physically realistic or not [165]. In addition, buddy checks are used for the comparison of observations close together and background checks consider a realistic change of the observation in comparison to the model prediction [165]. In comparison with a quality control, the number of institutes performing a snow data consistency check is lower. For this data preprocessing manual and automatic methods exist, based on basic physical principles, where the snow cover field is of particular importance. Consistency of snow height with the existence of snow cover is one of the commonly used checks, i.e., check if snow cover is present where observations of non-zero snow depth exist.

\subsection{Data Exchange Policy and Access Requirements for the Observations}

The survey indicates that two thirds of all answers were positive towards the possibility of snow data exchange with other groups. The NWP community seems more flexible compared to other modeling groups in this sense. This should be moderated by the fact that a relatively higher spatial resolution and catchment scale of hydrological applications could be a constraint on the feasibility of data exchange. In most cases GTS for NWP models and FTP protocol for the other models is required for data access, but web access or central data hubs are also used.

\subsection{The Plans to Use the New or Upcoming Observation Sources}

Concrete plans for using new or upcoming data sources of snow observations exist for all model environments, in particular for NWP with DA, hydrology, and reanalysis. In detailed answers of the survey, the use of more satellite data (optical, microwave) and also more ground-based remote sensing data, GPS or COSMIC ray sensors, or additional non-SYNOP networks are of interest. Current barriers and limitations for the use of these data are primarily data availability and lack of resources needed to integrate the data into the model environment. Survey responses showed these barriers to be common across model environments used. 


\section{Summary and Discussion}

According to the outcomes of the literature review, surveys and the action ES1404 itself together with HarmoSnow field campaigns and from snow HarmoSnow DA school activities, the key messages have been recognized and special attention is given to them in this section. These key items are (i) using conventional snow observations from national networks for DA and model validation, (ii) sustainable ways to create snow products for users by combining remote sensing and conventional snow observations with modeling results and (iii) snow observations errors for data assimilation and modelling systems.

\subsection{How to Get and Use Conventional Snow Observations from National Networks for Data Assimilation and Model Validation}

Data assimilation systems employed in model environments for numerical weather prediction, hydrology, or special snow models make extensive use of present-day measurement networks. The range of measurement instruments and techniques in use is also indicated by the results of the parallel considering COST HarmoSnow survey on in situ snow measurements [11]. The literature review reveals the importance of conventional snow observations for DA and model calibration and validation, and the potential benefits of obtaining additional observations from national networks, according to the survey responses, concrete plans for using new or upcoming data sources of snow observations exist for use in snow models of NWP, hydrology or other modeling environments.

Some strategies exist, or are underway, towards an improved and more extended usage of conventional snow observations to include observations from high-resolution national networks into NWP, hydrological and climate models, as the availability, and therefore use, of such data very limited [22,134]. They include the following: (1) The WMO "Snow Watch" initiative, which recognises the importance of near-real-time in situ observations of snow cover and snow depth to the global observing system. The Snow Watch action has secured approval by Executive Council 69 for an amendment to [166] in order to make daily reporting of snow cover and snow depth a mandatory requirement for all stations with the capability to do so. Of particular note, this explicitly includes the requirement to report values of zero snow depth, when snow is not present, in order to provide valuable additional information for assimilation into weather forecasting models. (2) The ECMWF data assimilation study with additional snow data $[22,134]$, clearly demonstrates the benefits to NWP forecast accuracy from assimilation of additional national network snow reports. (3) The monitoring of SYNOP station snow depth reports to detect problems in the snow analysis. A continuous monitoring allows also to identify progress in observation availability and frequency of reporting, which becomes more important with a broader application of automatic snow measurements [167].

\subsection{Sustainable Ways to Create Snow Products for Users by Combining Remote Sensing and Conventional Snow Observations with Modeling Results}

Until now, spaceborne derived snow products are not widely applied in operational NWP systems. In situ measurements are used to retrieve snow height for data assimilation, since for SWE the satellite products still not meet the requirements of DA in NWP. For SCE a number of combined and operational products exist, which includes also in situ measurements [168] and can be used to constrain the model SCE but SWE is the most interesting variable. Therefore, a number of blended satellite products have been developed, which merge visible, near-infrared, and passive microwave observations [169-172] and could be used for DA. Microwave satellite observations are combined with conventional in situ observations in some products (H-SAF), while optical satellite observations together with conventional in situ observations are assimilated into NWP models. The ESA GlobSnow project is another example providing combined products for models. It was shown recently by [94] that the coarse resolution of space-borne radiometers (in the order of tens of kilometers) for existing SWE products (H-SAF and GlobSnow) can be improved by assimilation together with in situ observations of snow depth, where the improved resolution enhances spatial details in the retrieved SWE. For hydrology, the DA is also 
very important for the implementation of spaceborne snow products used in streamflow forecasts. A variational method based on Moving Horizon Estimation (MHE) is used in [16], in application to the conceptual rainfall-runoff model HBV. Snow cover extent (SCE), snow water equivalent (SWE), soil moisture (SM) and in situ measurements of streamflow data were assimilated using large assimilation windows of up to one year. For the first time, H-SAF products were used for hydrological forecasting systems and their added value was verified. Although blended satellite products could serve in filling gaps of observation data or providing validation data, ideally, blending of products should happen only within the DA process due to the preferred separation of observation sources. Furthermore, blended products often contain information from models that have different assumptions than the model, which uses these products in assimilation.

\subsection{Snow Observations Errors for Data Assimilation and Modelling Systems}

Snow observations and products are subject to quality control as well as consistency checks, which are performed manually or automatically in the large majority of the model environments used in this survey. Furthermore, the observation error of snow measurements consisting of instrument error and representativeness error (e.g., $[173,174]$ is an important parameter used in snow DA. Results from the survey show that if an estimation of the observation error of snow measurements for DA is used, a prescribed constant value is chosen in many cases. The observation error sensitivity study performed with the ECMWF snow DA system showed the impact of this parameter on the global NWP forecast skills (Section 3.5, Figure 6). Since the observation error consists of two components for the derivation of this error from reported values in literature, the context of the measurements has to be taken into account [159,175-178].

The detailed review and assessment of the survey carried out by measurement communities [11] report on the quality of data and potential problems and provide valuable feedback for modelers on instrument errors. For instance, the results from the COST HarmoSnow field campaign in Iceland [16] showed that for SWE the observation error as relative standard deviation of $10 \%$ is possible if a suitable amount of measurements (i.e., minimum 3) is performed. However, this only account for the instrument error. In complex and windy terrains the total observation error can be much larger, which reflects the limited representativeness of snow measurements.

\section{Conclusions}

Based on the practices of a number of countries, review of the literature, and evaluation of the survey on use of snow observations in the modelling environment, conclusions can be drawn on: (i) the status and future evolution of conventional snow observations from national networks and satellite products for DA and model validation, including availability, error characteristics and reliability, towards an improved usage of conventional snow observations from national networks for data assimilation and model validation; (ii) the review of the methods to combine remote sensing and conventional snow observations with modeling results for user applications; and (iii) snow observations errors for data assimilation and modelling systems.

The results of the survey show that the measurement networks, instruments, and techniques are exploited well by existing DA systems and used in model environments for NWP, hydrology, or special snow models. The survey reveals that there is a fit between the snow macro-physical variables required for DA and those provided by the measurement environment, since snow depth, snow presence, snow density and SWE are the most measured variables. It is also important to take into consideration that in many cases these variables are measured with different instruments and techniques, in particular snow depth and SWE. On the other hand, developments in DA systems are necessary to exploit the evolving capabilities of the observing systems, and vice versa. The increasing automation of the measurements requires enhanced data management in the DA system (quality control, consistency). There is a requirement for remotely sensed snow depth or SWE observations from satellite, to provide snow data in regions with sparse measurement networks, but this necessitates developments in 
instrument technology (e.g., automatic measurement of snow microstructural properties) and also development of DA systems in order to make use of such observations. There are also concrete future plans on using enhanced snow observations for all model environments, in particular for NWP with DA, hydrology, and reanalysis. Data availability and resources to integrate the data in the model environment are the current barriers and limitations for the use of new or upcoming snow data sources independent of the model environment used.

The further outcomes from the survey support new, innovative and upgraded observing strategies; enhanced usage of snow data for scientific research and applications; a broader overview and easier access to existing snow measurements and snow model data for the benefit of different applications, such as NWP models, hydrological, climatology and climate change research. Further support of these aims is provided by the related COST HarmoSnow activities of the parallel survey on snow measurements and the training school on data assimilation in Europe [179]. The monitoring of floods, droughts, snow avalanches and hydropower production could benefit from improved real-time snow measurements for assimilation into operational prediction models to improve hydrological, meteorological and climate forecasting while a further integration and harmonization of the European snow network into global networks (e.g., WMO GCW) supports the strengthening WMO and EUMETSAT activities on snow observations. The main scientific impact will emerge from improved snow and weather products via better knowledge of snow properties and their evolution. It will induce a lasting structural improvement of the interaction between participating communities, thus very relevant for the Intergovernmental Panel on Climate Change (IPCC) and Copernicus (Global Monitoring for Environment and Security). Policy and decision makers at all levels from local safety to global environment policy will benefit from improved knowledge on current and future snow cover and climate conditions.

Supplementary Materials: COST ESSEM 1404 working group 3 survey: Questionnaire and results are available at http:/ / www.harmosnow.eu/index.php?page=WG3.

Author Contributions: Conceptualization, J.H., A.S.S., P.d.R., S.P., D.C.F, C.D.M., R.A.M., M.L., M.D., G.P., V.P., D.V.-S, A.N.A.; Methodology, J.H., A.S.S., P.d.R., S.P., D.C.F, C.D.M., R.A.M., M.L., M.D., G.P., V.P., D.V.-S, A.N.A.; Writing (original draft preparation), A.S.S., J.H., P.d.R., S.P., D.C.F, C.D.M., R.A.M., M.L., M.D., G.P., V.P., D.V.-S, A.N.A.; Writing (review and editing), J.H., A.S.S., P.d.R., S.P., D.C.F, C.D.M., R.A.M., M.L., M.D., G.P., V.P., D.V.-S, A.N.A.

Funding: This research is part of the COST Action ES1404 activity funded by the COST programme.

Acknowledgments: We thank all of the participants of the COST Action ES1404 for their support and fruitful comments to the results. We also thank all of the respondents to the survey who provided the material for this study. We are grateful to Sylvain Joffre, who had a key role in planning and initiating the COST Action ES1404.

Conflicts of Interest: The authors declare no conflict of interest.

\section{References}

1. Sui, J.; Koehler, G. Rain-on-snow induced flood events in southern Germany. J. Hydrol. 2001, 252, $205-220$. [CrossRef]

2. Drusch, M.; Vasiljevic, D.; Viterbo, P. ECMWF s global snow analysis: Assessment and revision based on satellite observations. J. Appl. Meteorol. 2004, 43, 1282-1294. [CrossRef]

3. Finger, D.; Heinrich, G.; Bauder, A. Projections of future water resources and their uncertainty in a glacierized catchment in the Swiss Alps and the subsequent effects on hydropower production during the 21st century. Water Resour. Res. 2012, 48, W02521. [CrossRef]

4. Viviroli, D.; Archer, D.R.; Buytaert, W.; Fowler, H.J.; Greenwood, G.B.; Hamlet, A.F.; Huang, Y.; Koboltschnig, G.; Litaor, M.I.; Lopez-Moreno, J.I.; et al. Climate change and mountain water resources: Overview and recommendations for research, management and policy. Hydrol. Earth Syst. Sci. 2011, 15, 471-504. [CrossRef]

5. Freudiger, D.; Kohn, I.; Stahl, K.; Weiler, M. Large-scale analysis of changing frequencies of rain-on-snow events with flood-generation potential. Hydrol. Earth Syst. Sci. 2014, 18, 2695-2709. [CrossRef] 
6. Fayad, A.; Gascoin, S.; Faour, G.; Lopez-Moreno, J.I.; Drapeau, L.; Le Page, M.; Escadafal, R. Snow Hydrology in Mediterranean Mountain Regions: A. Review. J. Hydrol. 2017, 551, 374-396. [CrossRef]

7. Lafaysse, M.; Cluzet, B.; Dumont, M.; Lejeune, Y.; Vionnet, V.; Morin, S. A multi physical ensemble system of numerical snow modeling. Cryosphere 2017, 11, 1173-1198. [CrossRef]

8. Etter, S.; Addor, N.; Huss, M.; Finger, D. Climate change impacts on future snow, ice and rain runoff in a Swiss mountain catchment using multi-dataset calibration. J. Hydrol. Reg. Stud. 2017, 13, 222-239. [CrossRef]

9. Sturm, M.; Goldstein, M.A.; Parr, C. Water and life from snow a trillion dollar science question. Water Resour. Res. 2017, 53, 3534-3544. [CrossRef]

10. Singh, P.; Singh, V.P. Snow and Glacier Hydrology; Kluwer Academic Publishers: Dordrecht, The Netherlands, 2001; p. 104.

11. Pirazzini, R.; Leppänen, L.; Picard, G.; Lopez-Moreno, J.I.; Marty, C.; Macelloni, G.; Kontu, A.; von Lerber, A.; Tanis, C.M.; Schneebeli, M.; et al. European In-Situ Snow Measurements: Practices and Purposes. Sensors 2018, 18, 2016. [CrossRef]

12. Hatchett, B.J.; McEvoy, D.J. Exploring the Origins of Snow Drought in the Northern Sierra Nevada. California. Earth Interact. 2018, 22, 1-13. [CrossRef]

13. Cline, D.; Yueh, S.; Chapman, B.; Stankov, B.; Gasiewski, A.; Masters, D.; Elder, K.; Kelly, R.; Painter, T.H.; Miller, S.; et al. NASA Cold Land Processes Experiment (CLPX 2002/03): Airborne Remote Sensing. J. Hyrdometerol. 2009, 10, 338-346. [CrossRef]

14. COST ESSEM 1404, Field Campaign in Chopok, Slovakia, 15-16 February $2016 . \quad$ Available online: http:/ / www.harmosnow.eu/dissemination/reports/Field\%20campaign\%20SK.pdf (accessed on 13 December 2018).

15. COST ESSEM 1404, Field Campaign in Erzurum, Turkey, 1-3 March 2016. Available online: http:/ / www.harmosnow.eu/dissemination/reports/Field_Campaign_Erzurum_2016.pdf (accessed on 13 December 2018).

16. COST ESSEM 1404, Field Campaign in Reykjavik, Iceland, 28 February 2 March 2017. Available online: http:/ / www.harmosnow.eu/dissemination/reports/COST_2nd_field_campaign_report.pdf (accessed on 13 December 2018).

17. Kim, E.; Gatebe, C.; Hall, D.; Newlin, J.; Misakonis, A.; Elder, K.; Marshall, H.; Hiemstra, C.; Brucker, L.; De Marco, E.; et al. NASA's snowex campaign: Observing seasonal snow in a forested environment. J. Geophys. Res. Atmos. 2017, 1388-1390. [CrossRef]

18. Potopová, V.; Boroneat, C.; Možný, M.; Soukup, J. Driving role of snow cover on soil moisture and drought developing during the growing season in the Czech Republic. Int J. Climatol. 2016, 36, 3741-3758. [CrossRef]

19. Dechant, C.M.; Moradkhani, H. Improving the characterization of initial condition for ensemble streamflow prediction using data assimilation. Hydrol. Earth Syst. Sci. 2011, 15, 3399-3410. [CrossRef]

20. Essery, R. Snowpack Modeling and Data Assimilation. ECMWF-WWRP/THORPEX Workshop on Polar Prediction. Available online: https:/ / www.ecmwf.int/sites/default/ files/elibrary/2013/13948-snowpackmodelling-and-data-assimilation.pdf (accessed on 13 December 2018).

21. Dong, C. Remote sensing, hydrological modeling and in-situ observations in snow cover research: A review. J. Hydrol. 2018. [CrossRef]

22. De Rosnay, P.; Mallas, I.; Gospodinov, I. Additional snow depth reports from Bulgaria: Data assimilation and recommendations. ECMWF Res. Memorandum 2016, RD16-178.

23. Key, J.; Goodison, B.; Schöne, W.; Godøy, Ø.; Ondráš, M.; Snorrason, Á. A Global Cryosphere Watch. ARCTIC 2015, 68, 48-58. [CrossRef]

24. World Meteorological Organization. Global Cryosphere Watch (2012) First Implementation Meeting; Final Report; World Meteorological Organization: Geneva, Switzerland, 2011.

25. De Lannoy, G.J.M.; Reichle, R.H.; Arsenault, K.R.; Houser, P.R.; Kumar, S.; Verhoest, N.E.C.; Pauwels, V.R.N. Multiscale assimilation of Advanced Microwave Scanning Radiometer-EOS snow water equivalent and Moderate Resolution Imaging Spectroradiometer snow cover fraction observations in northern Colorado. Water Resour. Res. 2012, 48, W01522. [CrossRef]

26. Hall, D.K.; Riggs, G.A.; Salomonson, V.V. Development of Methods for Mapping Global Snow Cover Using Moderate Resolution Imaging Spectroradiometer Data. Remote Sens. Environ. 1995, 54, 127-140. [CrossRef]

27. Klein, A.G.; Hall, D.K.; Riggs, G.A. Improving snow cover mapping in forests through the use of a canopy reflectance model. Hydrol. Process. 1998, 12, 1723-1744. [CrossRef] 
28. Metsämäki, S.; Vepsäläinen, J.; Pulliainen, J.; Sucksdorff, Y. Improved linear interpolation method for the estimation of snow-covered area from optical data. Remote Sens. Environ. 2002, 82, 64-78. [CrossRef]

29. Akyurek, Z.; Surer, S.; Beser, Ö. Investigation of the snow-cover dynamics in the Upper Euphrates Basin of Turkey using remotely sensed snow-cover products and hydrometeorological data. Hydrol. Process. 2011, 25, 3637-3648. [CrossRef]

30. Dietz, A.J.; Wohner, C.; Kuenzer, C. European Snow Cover Characteristics between 2000 and 2011 Derived from Improved MODIS Daily Snow Cover Products. Remote Sens. 2012, 4, 2432-2454. [CrossRef]

31. Parajka, J.; Bezak, N.; Burkhart, J.; Hauksson, B.; Holko, L.; Hundecha, Y.; Jenicek, M.; Krajčí, P.; Mangini, W.; Molnar, P.; et al. MODIS snowline elevation changes during snowmelt runoff events in Europe. J. Hydrol. Hydromech. 2018, 67, 101-109. [CrossRef]

32. Şorman, A.A.; Uysal, G.; Şensoy, A. Probabilistic snow cover and ensemble streamflow estimations in the Upper Euphrates Basin. J. Hydrol. Hydromech. 2018, 67, 82-92.

33. Simon, G.; Grizonnet, M.; Klempka, T.; Salgues, G. Algorithm theoretical basis documentation for an operational snow cover product from Sentinel-2 and Landsat-8 data (Let-it-snow). Zenodo 2018. [CrossRef]

34. Tekeli, A.E.; Akyurek, Z.; Sorman, A.A.; Sensoy, A.; Sorman, A.U. Using MODIS snow cover maps in modeling snowmelt runoff process in the eastern part of Turkey. Remote Sens. Environ. 2005, 97, 216-230. [CrossRef]

35. Immerzeel, W.W.; Droogers, P.; de Jong, S.M.; Bierkens, M.F.P. Large-scale monitoring of snow cover and runoff simulation in Himalayan river basins using remote sensing. Remote Sens. Environ. 2009, 113, 40-49. [CrossRef]

36. Finger, D.; Pellicciotti, F.; Konz, M.; Rimkus, S.; Burlando, P. The value of glacier mass balance, satellite snow cover images, and hourly discharge for improving the performance of a physically based distributed hydrological model. Water Resour. Res. 2011, 47, W07519. [CrossRef]

37. Marti, R.; Gascoin, S.; Berthier, E.; de Pinel, M.; Houet, T.; Laffly, D. Mapping snow depth in open alpine terrain from stereo satellite imagery. Cryosphere 2016, 10, 1361-1380. [CrossRef]

38. Parajka, J.; Blöschl, G. Validation of MODIS snow cover images over Austria. Hydrol. Earth Syst. Sci. Discuss. 2006, 3, 1569-1601. [CrossRef]

39. Parajka, J.; Blöschl, G. The value of MODIS snow cover data in validating and calibrating conceptual hydrologic models. J. Hydrol. 2008, 358, 240-258. [CrossRef]

40. Bavera, D.; De Michele, C. Snow Water Equivalent estimation in Mallero basin using snow gauge data and MODIS images and fieldwork validation. Hydrol. Process. 2009, 23, 1961-1972. [CrossRef]

41. Bavera, D.; De Michele, C.; Pepe, M.; Rampini, A. Melted snow volume control in the snowmelt runoff model using a snow water equivalent statistically based model. Hydrol. Process. 2012, 26, 3405-3415. [CrossRef]

42. Bavera, D.; Bavay, M.; Jonas, T.; Lehning, M.; De Michele, C. A comparison between two statistical and a physically-based model in snow water equivalent mapping. Adv. Water Resour. 2014, 63, 167-178. [CrossRef]

43. Finger, D.; Vis, M.; Huss, M.; Seibert, J. The value of multiple data set calibration versus model complexity for improving the performance of hydrological models in mountain catchments. Water Resour. Res. 2015, 51. [CrossRef]

44. Şorman, A.A.; Sensoy, A.; Tekeli, A.E.; Sorman, A.U.; Akyurek, Z. modeling and forecasting snowmelt runoff process using the HBV model in the eastern part of Turkey. Hydrol. Process. 2009, 23, 1031-1040. [CrossRef]

45. Şensoy, A.; Uysal, G. The value of snow depletion forecasting methods towards operational snowmelt runoff estimation using MODIS and Numerical Weather Prediction Data. Water Resour. Manag. 2012, 26, 3415-3440. [CrossRef]

46. Uysal, G.; Şensoy, A.; Şorman, A.A. Improving daily streamflow forecasts in mountainous Upper Euphrates basin by multi-layer perceptron model with satellite snow products. J. Hydrol. 2016, 543, 630-650. [CrossRef]

47. Finger, D. The value of satellite retrieved snow cover images to assess water resources and the theoretical hydropower potential in ungauged mountain catchments. Jökull 2018, in press.

48. Lee, S.; Klein, A.G.; Over, T.M. A comparison of MODIS and NOHRSC snowcover products for simulating streamflow using the Snowmelt Runoff Model. Hydrol. Process. 2005, 19, 2951-2972. [CrossRef]

49. Hall, D.K.; Riggs, G.A. Accuracy assessment of the MODIS snow products. Hydrol. Process. 2007, 21, 1534-1547. [CrossRef]

50. Da Ronco, P.; de Bárdossy, C. Cloud obstruction and snow cover in Alpine areas from MODIS products. Hydrol. Earth Syst. Sci. 2014, 18, 4579. [CrossRef] 
51. Gafurov, A.; Bárdossy, A. Cloud removal methodology from MODIS snow cover product. Hydrol. Earth Syst. Sci. 2009, 13, 1361-1373. [CrossRef]

52. Wang, X.; Xie, H. New methods for studying the spatiotemporal variation of snow cover based on combination products of MODIS Terra and Aqua. J. Hydrol. 2009, 371, 192-200. [CrossRef]

53. Hall, D.K.; Riggs, G.A.; Foster, J.L.; Kumar, S.V. Development and evaluation of a cloud-gap-filled MODIS daily snow-cover product. Remote Sens. Environ. 2010, 114, 496-503. [CrossRef]

54. Parajka, J.; Pepe, M.; Rampini, A.; Rossi, S.; Blöschl, G. A regional snow-line method for estimating snow cover from MODIS during cloud cover. J. Hydrol. 2010, 381, 203-212. [CrossRef]

55. Paudel, K.P.; Andersen, P. Monitoring snow cover variability in an agropastoral area in the Trans Himalayan region of Nepal using MODIS data with improved cloud removal methodology. Remote Sens. Environ. 2011, 115, 1234-1246. [CrossRef]

56. Arslan, A.; Tanis, C.; Metsämäki, S.; Aurela, M.; Böttcher, K.; Linkosalmi, M.; Peltoniemi, M. Automated Webcam Monitoring of Fractional Snow Cover in Northern Boreal Conditions. Geosciences 2017, 7, 55. [CrossRef]

57. Tanis, C.M.; Peltoniemi, M.; Linkosalmi, M.; Aurela, M.; Böttcher, K.; Manninen, T.; Arslan, A.N. A system for acquisition, processing and visualization of image time series from multiple camera networks. Data 2018, 3, 23. [CrossRef]

58. Pulliainen, J.T.; Hallikainen, M. Retrieval of regional snow water equivalent from spaceborne passive microwave observations. Remote Sens. Environ. 2001, 75, 76-85. [CrossRef]

59. Sun, C.; Walker, J.P.; Houser, P.R. A methodology for snow data assimilation in a land surface model. J. Geophys. Res. 2004, 109, D08108. [CrossRef]

60. Şorman, A.U.; Beser, O. Determination of snow water equivalent over the eastern part of Turkey using passive microwave data. Hydrol Process. 2013, 27, 1945-1958. [CrossRef]

61. Jörg-Hess, S.; Griessinger, N.; Zappa, M. Probabilistic Forecasts of Snow Water Equivalent and Runoff in Mountainous Areas. J. Hydrometeorol. 2015, 16, 2169-2186.

62. Slater, A.G.; Clark, M.P. Snow data assimilation via an ensemble Kalman filter. J. Hydrometeorol. 2006, 7, 478-493. [CrossRef]

63. Foster, J.L.; Sun, C.; Walker, J.P.; Kelly, R.; Chang, A.; Dong, J.; Powell, H. Quantifying the uncertainty in passive microwave snow water equivalent observations. Remote Sens. Environ. 2005, 92, 187-203. [CrossRef]

64. Dong, J.; Walker, J.P.; Houser, R.P. Factors affecting remotely sensed snow water equivalent uncertainty. Remote Sens. Environ. 2005, 97, 68-82. [CrossRef]

65. Cordisco, E.; Prigent, C.; Aires, F. Snow characterization at a global scale with passive microwave satellite observations. J. Geophys. Res. 2006, 111, D19102. [CrossRef]

66. Kelly, R.E.J. The AMSR-E Snow Depth Algorithm: Description and Initial Results. J. Remote Sens. Soc. 2009, 29, 307-317.

67. Tedesco, M.; Reichle, R.; Loew, A.; Markus, T.; Foster, J.L. Dynamic Approaches for Snow Depth Retrieval from Spaceborne Microwave Brightness Temperature. IEEE Trans. Geosci. Remote Sens. 2010, 48, 1955-1967. [CrossRef]

68. Tedesco, M.; Narvekar, P. Assessment of the NASA AMSR-E SWE Product. IEEE J. Sel. Top. Appl. Earth Observ. Remote Sens. 2010, 3, 141-159. [CrossRef]

69. Leppänen, L.; Kontu, A.; Vehviläinen, J.; Lemmetyinen, J.; Pulliainen, J. Comparison of traditional and optical grain-size field measurements with SNOWPACK simulations in a taiga snowpack. J. Glaciol. 2015, 61, 151-162. [CrossRef]

70. Li, X.; Zhang, L.; Hermüller, L.; Jiang, L.; Vereecken, H. Measurement and Simulation of Topographic Effects on Passive Microwave Remote Sensing Over Mountain Areas. A Case Study from the Tibetan Plateau. Geosc. Remote Sens. 2014, 52, 1489-1501. [CrossRef]

71. Kontu, A.; Lemmetyinen, J.; Vehviläinen, J.; Leppänen, L.; Pulliainen, J. Coupling SNOWPACK-modeled grain size parameters with the HUT snow emission model. Remote Sens. Environ. 2017, 194, 33-47. [CrossRef]

72. Conde, V.; Nico, G.; Mateus, P.; Catalão, J.; Kontu, A.; Gritsevich, M. On the estimation of temporal changes of snow water equivalent by spaceborne SAR interferometry: A new application for the Sentinel-1 mission. J. Hydrol. Hydromech. 2018, 67, 93-100. [CrossRef]

73. Armstrong, R.; Brun, E. Snow and Climate: Physical Processes, Surface Energy Exchange and Modeling; Cambridge University Press: Cambridge, UK, 2008. 
74. De Michele, C.; Avanzi, F.; Ghezzi, A.; Jommi, C. Investigating the dynamics of bulk snow density in dry and wet conditions using a one-dimensional model. Cryosphere 2013, 7, 433-444. [CrossRef]

75. Koivusalo, H.; Heikinheimo, M.; Karvonen, T. Test of a simple two-layer parameterisation to simulate the energy balance and temperature of a snowpack. Theor. Appl. Climatol. 2001, 70, 65-79. [CrossRef]

76. Lehning, M.; Bartelt, P.B.; Brown, R.L.; Fierz, C.; Satyawali, P. A physical SNOWPACK model for the Swiss Avalanche Warning Services. Part II: Snow Microstructure. Cold Reg. Sci. Technol. 2002, 35, 147-167. [CrossRef]

77. Lehning, M.; Bartelt, P.B.; Brown, R.L.; Fierz, C.; Satyawali, P. A physical SNOWPACK model for the Swiss Avalanche Warning Services. Part III: Meteorological Boundary Conditions, Thin Layer Formation and Evaluation. Cold Reg. Sci. Technol. 2002, 35, 169-184. [CrossRef]

78. Vionnet, V.; Brun, E.; Morin, S.; Boone, A.; Faroux, S.; le Moigne, P.; Martin, E.; Willemet, J.M. The detailed snowpack 6209 scheme Crocus and its implementation in SURFEX v7.2. Geosci. Model Dev. 2012, 5, 773-791. [CrossRef]

79. Dutra, E.; Viterbo, P.; Miranda, P.; Balsamo, G. Complexity of Snow Schemes in a Climate Model and Its Impact on Surface Energy and Hydrology. J. Hydrometeorol. 2012, 13, 521-538. [CrossRef]

80. Best, M.J.; Pryor, M.; Clark, D.B.; Rooney, G.G.; Essery, R.L.H.; Menard, C.B.; Edwards, J.; Hendry, M.A.; Porson, A.; Gedney, N.; et al. The Joint UK Land Environment Simulator (JULES), model description-Part 1: Energy and water fluxes. Geosci. Model Dev. 2011, 4, 677-699. [CrossRef]

81. Boone, A. Description du Schema de Neige ISBA-ES (Explicit Snow); Centre National de Recherches: Toulouse, France, 2002.

82. Zängl, G.; Reinert, D.; Ripodas, P. The ICON (ICOsahedral Non-hydrostatic) modeling framework of DWD and MPI-M: Description of the non-hydrostatic dynamical core. Q. J. R. Meteorol. Soc. 2014, 141, 563-579. [CrossRef]

83. Carmagnola, C.M.; Morin, S.; Lafaysse, M.; Domine, F.; Lesaffre, B.; Lejeune, Y.; Picard, G.; Arnaud, L. Implementation and evaluation of prognostic representations of the optical diameter of snow in the SURFEX/ISBA-Crocus detailed snowpack model. Cryosphere 2014, 8, 417-437. [CrossRef]

84. Avanzi, F.; De Michele, C.; Ghezzi, A.; Jommi, C.; Pepe, M. A processing-modeling routine to use SNOTEL hourly data in snowpack dynamic models. Adv. Water Resour. 2014, 73, 16-29. [CrossRef]

85. Slater, A.G.; Schlosser, C.A.; Desborough, C.E.; Pitman, A.J.; Henderson-Sellers, A.; Robock, A.; Vinnikov, K.Y.; Mitchell, K.; Boone, A.; Braden, H.; et al. The representation of snow in land-surface schemes: Results from PILPS 2(d). J. Hydrometeorol. 2001, 2, 7-25. [CrossRef]

86. Rutter, N.; Essery, R.; Pomeroy, J.; Altimir, N.; Andreadis, K.; Baker, I.; Yamazaki, T. Evaluation of forest snow processes models (SnowMIP2). J. Geophys. Res. 2009, 114, 18. [CrossRef]

87. Dutra, E.; Balsamo, G.; Viterbo, P.; Miranda, P.M.A.; Beljaars, A.C.M.; Schär, C.; Elder, K. An improved snow scheme for the ECMWF land surface model: Description and offline validation. J. Hydrometeor. 2010, 11, 899-916. [CrossRef]

88. Andreadis, K.M.; Lettenmaier, D.P. Assimilating remotely sensed snow observations into a macroscale hydrology model. Adv. Water Resour. 2006, 29, 872-886. [CrossRef]

89. Clark, M.P.; Slater, A.G.; Barrett, A.P.; Hay, L.E.; Mccabe, G.J.; Rajagopalan, B.; Leavesley, G.H. Assimilation of snow covered area information into hydrologic and land-surface models and land-surface models. Adv. Water Resour. 2006, 29, 1209-1221. [CrossRef]

90. Leisenring, M.; Moradkhani, H. Snow water equivalent prediction using Bayesian data assimilation methods. Stoch. Environ. Res. Risk A 2011, 25, 253-270. [CrossRef]

91. Nagler, T.; Rott, H.; Malcher, P.; Müller, F. Assimilation of meteorological and remote sensing data for snowmelt runoff forecasting. Remote Sens. Environ. 2008, 112, 1408-1420. [CrossRef]

92. Liu, Y.; Peters-Lidard, C.D.; Kumar, S.; Foster, J.L.; Shaw, M.; Tian, Y.; Fall, G.M. Assimilating satellite-based snow depth and snow cover products for improving snow predictions in Alaska. Adv. Water Resour. 2013, 54, 208-227. [CrossRef]

93. Saloranta, T.M. Operational snow mapping with simplified data assimilation using the seNorge snow model. J. Hydrol. 2016, 538, 314-325. [CrossRef]

94. Takala, M.; Ikonen, J.; Luojus, K.; Lemmetyinen, J.; Metsämäki, S.; Cohen, J.; Arslan, A.; Pulliainen, J. New Snow Water Equivalent Processing System with Improved Resolution Over Europe and its Applications in Hydrology. IEEE J. Sel. Top. Appl. Earth Observ. Remote Sens. 2017, 10, 428-436. [CrossRef] 
95. Fletcher, S.J.; Liston, G.E.; Hiemstra, C.A.; Miller, S.D. Assimilating MODIS and AMSR-E snow observations in a snow evolution model. J. Hydrometeorol. 2012, 13, 1475-1492. [CrossRef]

96. Bergeron, J.M.; Trudel, M.; Leconte, R. Combined assimilation of streamflow and snow water equivalent for mid-term ensemble streamflow forecasts in snow-dominated regions. Hydrol. Earth Syst. Sci. 2016, 20, 4375-4389. [CrossRef]

97. Charrois, L.; Cosme, E.; Dumont, M.; Lafaysse, M.; Morin, S.; Libois, Q.; Picard, G. On the assimilation of optical reflectances and snow depth observations into a detailed snowpack model. Cryosphere 2016, 10, 1021-1038. [CrossRef]

98. Dziubanski, D.J.; Franz, K.J. Assimilation of AMSR-E snow water equivalent data in a spatially-lumped snow model. J. Hydrol. 2016, 540, 26-39. [CrossRef]

99. Griessinger, N.; Seibert, J.; Magnusson, J.; Jonas, T. Assessing the benefit of snow data assimilation for runoff modeling www.hydrol-earth-syst-sci.net/21/635/2017/. Hydrol. Earth Syst. Sci. 2017, 21, 635-650.

100. Alvarado-Montero, R.; Schwanenberg, D.; Krahe, P.; Lisniak, D.; Sensoy, A.; Sorman, A.; Akkol, B. Moving Horizon Estimation for Assimilating H-SAF Remote Sensing Data into the HBV Hydrological Model. Adv. Water Resour. 2016, 92, 248-257. [CrossRef]

101. Huang, C.; Newman, A.J.; Clark, M.P.; Wood, A.W.; Zheng, X. Evaluation of snow data assimilation using the ensemble Kalman filter for seasonal streamflow prediction in the western United States. Hydrol. Earth Syst. Sci. 2017, 21, 635-650. [CrossRef]

102. Piazzi, G.; Thirel, G.; Campo, L.; Gabellani, S. A particle filter scheme for multivariate data assimilation into a point-scale snowpack model in an Alpine environment. Cryosphere 2018, 12, 2287-2306. [CrossRef]

103. Liston, G.; Hiemstra, C.A. A simple data assimilation system for complex snow distributions (SnowAssim). J. Hydrometeorol. 2008, 9, 989-1004. [CrossRef]

104. Liston, G.E.; Pielke, R.A., Sr.; Greene, E.M. Improving first-order snow-related deficiencies in a regional climate model. J. Geophys. Res. 1999, 104, 19559-51567. [CrossRef]

105. Houser, P.R.; De Lannoy, G.; Walker, J.P. Land Surface Data Assimilation, p549-598. In Data Assimilation: Making Sense of Observations; Lahoz, W., Khatattov, B., Menard, R., Eds.; Springer: Dordrecht, The Netherlands, 2010; p. 732.

106. Barrett, A.P. National operational hydrologic remote sensing center snow data assimilation system (SNODAS) products at NSIDC. Special Rep. 11, NSIDC: Boulder, CO, USA, 2003; p. 19. Available online: https: //nsidc.org/pubs/documents/special/nsidc_special_report_11.pdf (accessed on 14 December 2018).

107. Brasnett, B. A global analysis of snow depth for numerical weather prediction. J. App. Meteorol. 1999, 38, 726-740. [CrossRef]

108. Rodell, M.; Houser, P.R. Updating a land surface model with MODIS-derived snow cover. J. Hydrometeorol. 2004, 5, 1064-1075. [CrossRef]

109. Zaitchik, B.F.; Rodell, M. Forward-looking assimilation of MODIS-derived snow-covered area into a land surface model. J. Hydrometeorol. 2009, 10, 130-148. [CrossRef]

110. Dong, J.; Walker, J.; Houser, P.; Sun, C. Scanning multichannel microwave radiometer snow water equivalent assimilation. J. Geophys. Res. 2007, 112, D07108. [CrossRef]

111. Durand, M.; Margulis, S.A. Feasibility test of multifrequency radiometric data assimilation to estimate snow water equivalent. J. Hydrometeorol. 2006, 7, 443-457. [CrossRef]

112. Durand, M.; Margulis, S.A. Correcting first-order errors in snow water equivalent estimates using a multifrequency, multiscale radiometric data assimilation scheme. J. Geophys. Res. 2007, 112, D13. [CrossRef]

113. Andreadis, K.M.; Liang, D.; Tsang, L.; Lettenmaier, D.P.; Josberger, E.G. Characterization of errors in a coupled snow hydrology-microwave emission model. J. Hydrometeorol. 2008, 9, 149-164. [CrossRef]

114. Durand, M.; Kim, E.J.; Margulis, S.A. Radiance assimilation shows promise for snowpack characterization. Geophys. Res. Lett. 2009, 36. [CrossRef]

115. Che, T.; Li, X.; Jin, R.; Huang, C. Assimilating passive microwave remote sensing data into a land surface model to improve the estimation of snow depth. Remote Sens. Environ. 2014, 143, 54-63. [CrossRef]

116. Li, D.; Durand, M.; Margulis, S. Estimating snow water equivalent in a Sierra Nevada watershed via spaceborne radiance data assimilation. Water Resour. Res. 2017, 53. [CrossRef]

117. Larue, F.; Royer, A.; De Sève, D.; Roy, A.; Picard, G.; Vionnet, V. Simulation and assimilation of passive microwave data using a snowpack model coupled to a calibrated radiative transfer model over northeastern Canada. Water Resour. Res. 2018, 54, 4823-4848. [CrossRef] 
118. Larue, F.; Royer, A.; De Sève, D.; Roy, A.; Cosme, E. Assimilation of passive microwave AMSR-2 satellite observations in a snowpack evolution model over North-Eastern Canada. Hydrol. Earth Syst. Sci. Discuss. 2018. under review. [CrossRef]

119. Kwon, Y.; Toure, A.M.; Yang, Z.-L.; Rodell, M.; Picard, G. Error characterization of the coupled land surface-radiative transfer models for snow passive microwave radiance assimilation. IEEE Trans. Geosci. Remote Sens. 2015, 53, 5247-5268. [CrossRef]

120. Lemmetyinen, J.; Pulliainen, J.; Rees, A.; Kontu, A.; Qiu, Y.; Derksen, C. Multiple-Layer Adaptation of HUT Snow Emission Model. Comparison with Experimental Data. IEEE Tran. Geosci. Remote Sens. 2010, 48, 2781-2794. [CrossRef]

121. Wiesmann, A.; Mätzler, C. Microwave emission model of layered snowpacks. Remote Sens. Environ. 1999, 70, 307-316. [CrossRef]

122. Tsang, L.; Pan, J.; Liang, D.; Li, Z.; Cline, D. Modeling Active Microwave Remote Sensing of Snow using Dense Media Radiative Transfer (DMRT) Theory with Multiple Scattering Effects. IEEE Int. Symp. Geosci. Remote Sens. 2006. [CrossRef]

123. Picard, G.; Brucker, L.; Roy, A.; Dupont, F.; Fily, M.; Royer, A. Simulation of the microwave emission of multi-layered snowpacks using the dense media radiative transfer theory, the DMRT-ML model. Geosci. Model Dev. 2013. [CrossRef]

124. Royer, A.; Roy, A.; Montpetit, B.; Saint-Jean-Rondeau, O.; Picard, G.; Brucker, L.; Langlois, A. Comparison of commonly-used microwave radiative transfer models for snow remote sensing. Remote Sens. Environ. 2017, 190, 247-259. [CrossRef]

125. Löwe, H.; Picard, G. Microwave scattering coefficients of snow in MEMLS and DMRT-ML revisited: The relevance of sticky hard spheres and tomography-based estimates of stickiness. Cryosphere 2015, 9, 2101-2117. [CrossRef]

126. Pan, J.; Durand, M.; Sandells, M.; Lemmetyinen, J.; Kim, E.J.; Pulliainen, J. Differences between the HUT Snow Emission Model and MEMLS and Their Effects on Brightness Temperature Simulation. IEEE Trans. Geosci. Remote Sens. 2016, 54, 2001-2019. [CrossRef]

127. Picard, G.; Sandells, M.; Löwe, H. SMRT: An active-Passive microwave radiative transfer model for snow with multiple microstructure and scattering formulations (v1.0). Geosci. Model Dev. 2018, 11, 2763-2788. [CrossRef]

128. Sandells, M.; Essery, R.; Rutter, N.; Wake, L.; Leppänen, L.; Lemmetyinen, J. Microstructure representation of snow in coupled snowpack and microwave emission models. Cryosphere 2017, 11, 229-246. [CrossRef]

129. COST ESSEM 1404, Memorandum of Understanding, Brussels, 15 May, 2015, COST 032/14. Available online: https:/ / e-services.cost.eu/files/domain_files/ESSEM/Action_ES1404/mou/ES1404-e.pdf (accessed on 13 December 2018).

130. Malik, N.; Bookhagen, B.; Marwan, N.; Kurths, J. Analysis of spatial and temporal extreme monsoonal rainfall over South Asia using complex networks. Clim. Dyn. 2012, 39, 971-987. [CrossRef]

131. Cressman, G.P. An operational objective analysis system. Mon. Weather Rev. 1959, 87, 367-374. [CrossRef]

132. Dee, D.; Uppala, S.; Simmons, A.; Berrisford, P.; Poli, P.; Kobayashi, S.; Andrae, U.; Balsameda, M.; Balsamo, G.; Bauer, P.; et al. The ERA-Interim reanalysis: Configuration and performance of the data assimilation system. Q. J. R. Meteorol. Soc. 2011, 137, 553-597. [CrossRef]

133. De Rosnay, P.; Balsamo, G.; Albergel, C.; Muñoz-Sabater, J.; Isaksen, L. Initialisation of land surface variables for Numerical Weather Prediction. Surv. Geophys. 2014, 35, 607-621. [CrossRef]

134. De Rosnay, P.; Isaksen, L.; Dahoui, M. Snow data assimilation at ECMWF. ECMWF Newslett. 2015, 143, $26-31$.

135. Stauffer, D.R.; Seaman, N.L. Use of four-dimensional data assimilation in a limited-area mesoscale model. Part I: Experiments with synoptic-scale data. Mon. Weather Rev. 1990, 118, 1250-1277. [CrossRef]

136. Boni, G.; Castelli, F.; Gabellani, S.; Machiavello, G.; Rudari, R. Assimilation of MODIS snow cover and real time snow depth point data in a snow dynamic model. Geosci. Remote Sens. Symp. 2010, 1788-1791. [CrossRef]

137. Kalman, R.E. A new approach to linear filtering and prediction problems. J. Basic Eng. 1960, 82, 35-45. [CrossRef]

138. Gelb, A. Optimal linear filtering. In Applied Optimal Estimation; MIT Press: Cambridge, MA, USA, 1974; pp. 102-155. 
139. Miller, R.N.; Ghil, M.; Gauthiez, F. Advanced data assimilation in strongly nonlinear dynamical systems. J. Atmos. Sci. 1994, 51, 1037-1056. [CrossRef]

140. Moradkhani, H. Hydrologic remote sensing and land surface data assimilation. Sensors 2008, 8, $2986-3004$. [CrossRef]

141. Evensen, G. Sequential data assimilation with a nonlinear quasi-geostrophic model using Monte Carlo methods to forecast error statistics. J. Geophys. Res. 1994, 99, 10143-10162. [CrossRef]

142. Evensen, G. The Ensemble Kalman Filter: Theoretical formulation and practical implementation. Ocean Dynam. 2003, 53, 343-367. [CrossRef]

143. Arulampalam, M.S.; Maskell, S.; Gordon, N.; Clapp, T. A tutorial on particle filters for on-line nonlinear/non-Gausssian Bayesin tracking. IEEE Trans. Signal Process. 2002, 50, 174-188. [CrossRef]

144. Moradkhani, H.; Sorooshian, S.; Gupta, H.V.; Houser, P.R. Dual state-Parameter estimation of hydrological models using ensemble Kalman filter. Adv. Water Resour. 2005, 28, 135-147. [CrossRef]

145. Zhou, Y.; McLaughlin, D.; Entekhabi, D. Assessing the performance of the ensemble Kalman filter for land surface data assimilation. Mon. Wea. Rev. 2006, 134, 2128-2142. [CrossRef]

146. Moradkhani, H.; Sorooshian, S. General review of rainfall-runoff modeling, model calibration, data assimilation, and uncertainty analysis. Hydrol. Model. Water Cycle 2009, 63, 1-24.

147. Montzka, C.; Moradkhani, H.; Weihermuller, L.; Canty, M.; Hendricks Franssen, H.J.; Vereecken, H. Hydraulic Parameter Estimation by Remotely-sensed top Soil Moisture Observations with the Particle Filter. J. Hydrol. 2011, 399, 410-421. [CrossRef]

148. Bocquet, M.; Pires, C.A.; Wu, L. Beyond Gaussian statistical modeling in geophysical data assimilation (Review). Mon. Weather Rev. 2010, 138, 2997-3023. [CrossRef]

149. Li, Z.; Navon, I.M. Optimality of variational data assimilation and its relationship with the Kalman filter and smoother. Q. J. R. Meteorol. Soc. 2001, 127, 661-683. [CrossRef]

150. Allgöwer, F.; Badgwell, T.A.; Qin, J.S.; Rawlings, J.B.; Wright, S.J. Nonlinear Predictive Control and Moving Horizon Estimation An Introductory Overview. In Advances in Control, Highlights of ECC99; Frank, P.M., Ed.; Springer Verlag: Berlin, Germany, 1999; pp. 391-449.

151. Alvarado-Montero, R.; Schwanenberg, D.; Krahe, P.; Helmke, P.; Klein, B. Multi-parametric variational data assimilation for hydrological forecasting. Adv. Water Resour. 2017, 110, 182-192. [CrossRef]

152. Su, H.; Yang, Z.L.; Niu, G.Y.; Dickinson, R.E. Enhancing the estimation of continental-scale snow water equivalent by assimilating MODIS snow cover with the ensemble Kalman filter. J. Geophys. Res. Atmos. 2008, 113, D08120. [CrossRef]

153. Kumar, S.V.; Reichle, R.H.; Peters-Lidard, C.D.; Koster, R.D.; Zhan, X.; Crow, W.T.; Eylander, J.B.; Houser, P.R. A land surface data assimilation framework using the land information system: Description and applications. Adv. Water Resour. 2008, 31, 1419-1432. [CrossRef]

154. Durand, Y.; Laternser, M.; Giraud, G.; Etchevers, P.; Lesaffre, L.; Mérindol, L. Reanalysis of 44 year of climate in the French Alps (1958-2002): Methodology, model validation, climatology, and trends for air temperature and precipitation. J. Appl. Meteorol. Clim. 2009, 48, 29-449.

155. Durand, Y.; Laternser, M.; Giraud, G.; Etchevers, P.; Mérindol, L.; Lesaffre, B. Reanalysis of 47 Years of Climate in the French Alps (1958-2005): Climatology and Trends for Snow Cover. J. Appl. Meteorol. Clim. 2009, 48, 2487-2512. [CrossRef]

156. Toure, A.M.; Goïta, K.; Royer, A.; Kim, E.J.; Durand, M.; Margulis, S.A.; Lu, H. A case study of using a multilayered thermodynamical snow model for radiance assimilation. IEEE Trans. Geosci. Remote Sens. 2011, 49, 2828-2837. [CrossRef]

157. Durand, M.; Margulis, S.A. Effects of uncertainty magnitude and accuracy on assimilation of multi-scale measurements for snowpack characterization. J. Geophys. Res. Atmos. 2008, 113, D02105. [CrossRef]

158. Su, H.; Yang, Z.-L.; Dickinson, R.E.; Wilson, C.R.; Niu, G.-Y. Multisensor snow data assimilation at the continental scale: The value of Gravity Recovery and Climate Experiment terrestrial water storage information. J. Geophys. Res. 2010, 115, D10104. [CrossRef]

159. Magnusson, J.; Gustafsson, D.; Hüsler, F.; Jonas, T. Assimilation of point SWE data into a distributed snow cover model comparing two contrasting methods. Water Resour. Res. 2014, 50, 7816-7835. [CrossRef]

160. Griessinger, N.; Seibert, J.; Magnusson, J.; Jonas, T. Evaluation of snow data assimilation in Alpine catchments. Hydrol. Earth Syst. Sci. 2016, 20, 3895-3905. [CrossRef] 
161. Magnusson, J.; Winstral, A.; Stordal, A.S.; Essery, R.; Jonas, T. Improving physically based snow simulations by assimilating snow depths using the particle filter. Water Resour. Res. 2017, 53, 1125-1143. [CrossRef]

162. Pullen, S.; Jones, C.; Rooney, G. Using satellite-derived snow cover data to implement a snow analysis in the met office NWP model. J. Appl. Meteorol. 2011, 50, 958-973. [CrossRef]

163. Del Moral, P. Non Linear Filtering: Interacting Particle Solution. Markov Process. Relat. Fields 1996, 2, 555-580.

164. Rood, R.B.; Cohn, S.E.; Coy, L. Data assimilation for EOS: The value of assimilated data. Part 1. Earth Obs. 1994, 6, 23-25.

165. Walker, J.P.; Houser, P.R. Hydrologic data assimilation. In Advances in Water Science Methodologies; Balkema: Rotterdam, The Netherlands, 2005; p. 230.

166. World Meteorological Organization (WMO). Manual on the Global Observing System, Volume I-Global aspects: Annex $V$ to the WMO Technical Regulations; (2015 edition, updated in 2017), WMO- No. 544; WMO: Geneva, The Switzerland, 2015; ISBN 978-92-63-10544-8.

167. Workshop Report 1st Snow Data Assimilation Workshop in the framework of COST HarmoSnow ESSEM 1404. Available online: https://www.schweizerbart.de/papers/metz/detail/prepub/89726/Workshop_ Report_1st_Snow_Data_Assimilation_Workshop_in_the_framework_of_COST_HarmoSnow_ESSEM_ 1404 (accessed on 13 December 2018).

168. Ramsay, B. The interactive multisensor snow and ice mapping system. Hydrol. Process. 1998, 12, 1537-1546. [CrossRef]

169. Kongoli, C.; Dean, C.; Helfrich, S.; Ferraro, R. Evaluating the potential of a blended passive microwave-interactive multi-sensor product for improved mapping of snow cover and estimations of snow water equivalent. Hydrol. Process. 2007, 21, 1597-1607. [CrossRef]

170. Gao, Y.; Xie, H.J.; Lu, N.; Yao, T.D.; Liang, T.G. Toward advanced daily cloud-free snow cover and snow water equivalent products from Terra-Aqua MODIS and Aqua AMSR-E measurements. J. Hydrol. 2010, 385, 23-35. [CrossRef]

171. Akyurek, Z.; Hall, D.K.; Riggs, G.A.; Sorman, A.U. Evaluating the utility of the ANSA blended snow cover product in the mountains of eastern Turkey. Int. J. Remote Sens. 2010, 31, 3727-3744. [CrossRef]

172. Foster, J.L.; Hall, D.K.; Eylander, J.B.; Riggs, G.A.; Nghiem, S.V.; Tedesco, M.; Kim, E.J.; Montesano, P.M.; Kelly, R.E.J.; Casey, K.A.; et al. A blended global snow product using visible, passive microwave and scatterometer data. Int. J. Remote Sens. 2011, 32, 1371-1395. [CrossRef]

173. Janjić, T.; Bormann, N.; Bocquet, M.; Carton, J.A.; Cohn, S.E.; Dance, S.L.; Losa, S.N.; Nichols, N.K.; Potthast, R.; Waller, J.A.; et al. On the representation error in data assimilation. Q. J. R. Meteorol. Soc. 2017, 144, 713. [CrossRef]

174. Kurzeneva, E.; Choulga, M.; Rontu, L. Error Statistics in Data Assimilation for NWP: Perspectives for Snow. In Proceedings of the Workshop: Towards a Better Harmonization of Snow Observations, Modeling and Data Assimilation in Europe, Budapest, Hungary, 30-31 October 2018.

175. Kumar, S.V.; Peters-Lidard, C.D.; Arsenault, K.R.; Getirana, A.; Mocko, D. Quantifying the added value of snow cover area observations in passive microwave snow depth assimilation. J. Hydrometeor. 2015, 16, 1736-1741. [CrossRef]

176. He, M. Data Assimilation in Watershed Models for Improved Hydrologic Forecasting. Ph.D Thesis, University of California, Los Angeles, CA, USA, 2010; p. 173.

177. He, M.; Hogue, T.S.; Franz, K.J.; Margulis, S.A. An integrated uncertainty and ensemble-based data assimilation framework for improved operational streamflow predictions. Hydrol. Earth Syst. Sci. 2012, 16, 815-831. [CrossRef]

178. Franz, K.J.; Hogue, T.S.; Barik, M.; He, M. Assessment of SWE data assimilation for ensemble streamflow predictions. J. Hydrol. 2014, 519, 2737-2746. [CrossRef]

179. COST ESSEM 1404, Training School on Snow Observations and Data Assimilation in Bormio, 12-16 March 2018. Available online: http:/ / www.harmosnow.eu/index.php?page=Training\%20School\%20Bormio (accessed on 13 December 2018).

(C) 2018 by the authors. Licensee MDPI, Basel, Switzerland. This article is an open access article distributed under the terms and conditions of the Creative Commons Attribution (CC BY) license (http:// creativecommons.org/licenses/by/4.0/). 